\title{
The Repugnant Other: Soldiers, Missionaries, and Aid Workers as Organizational Migrants ${ }^{1}$
}

\author{
LEO LUCASSEN AND ANIEK X. SMIT \\ Institute for History, Leiden University
}

\begin{abstract}
M OsT people do not consider diplomats, corporate expatriates, missionaries, scholars, or soldiers to be migrants. Even migration scholars often pay little attention to people whose migratory behavior is primarily determined by the interests of the organization they work for. The reason for this blind spot is not the lack of analytical tools. In his landmark I97I paper on the mobility transition, the geographer Wilbur Zelinsky already acknowledged the importance of such-often highly skilled-migrants. Five years later, Charles Tilly made a similar point in his migration typology, which was adopted in the overview of migration in Western Europe by Leslie Page Moch, ${ }^{2}$ by explicitly distinguishing "career migrants." ${ }^{3}$ Notwithstanding the inclusion of what we
\end{abstract}

1 An earlier version of this article was presented at the annual conference of the SSHA in Chicago (November 2013). We thank Ulbe Bosma, Nancy L. Green, Karwan FatahBlack, Jeanette Kamp, Lynn Hollen Lees, Marcel van der Linden, Jan Lucassen, Leslie Moch, Lewis Siegelbaum, and Wim Willems for their constructive criticism on an earlier version.

2 L. P. Moch, Moving Europeans. Migration in Western Europe since I650 (Bloomington: Indiana University Press, I992, 2003).

3 W. Zelinsky, "The Hypothesis of the Mobility Transition," Geographical Review 6I, no. 2 (I97I): 219-249; C. Tilly, "Migration in Modern European History," CRSO Working Paper (Ann Arbor: University of Michigan Press, 1976), I45; C. Tilly, "Migration in Modern European History," in Human Migration: Patterns and Policies, ed. W. H. McNeill and B. Adams (Bloomington: Indiana University Press, I978), 48-72.

Journal of World History, Vol. 25, No. 4

(C) 2014 by University of Hawai'i Press 
label "organizational migrants" by leading scholars, in the mainstream migration historiography attention to their mobility is conspicuously lacking.

Given the conventional — and often political and policy-drivendefinitions of what constitutes a migrant, this need not come as a surprise. Most people still conceive of migrants as people who decide to move to a faraway country with the aim to stay there for the rest of their lives, learn the language, join the new community, and assimilate, or, depending on the prevailing membership regime and preferences of the migrants themselves, establish long-term recognizable ethnic communities. ${ }^{4}$ Over the last half century this stereotypical "one-way-moveand-settle" image has been revised thoroughly by migration scholars, and the "toolbox" now also consists of concepts such as return migration, sojourning, transnationalism, diaspora, and the like. ${ }^{5}$ This broadening of the perspective, however, has only very partially reached as far as the people we call organizational migrants, such as soldiers, corporate expatriates, diplomats, missionaries, scholars and aid workers.

This persistent exclusion seems to result from the following mix of assumptions about organizational migrants:

I. Organizational migrants often move only temporarily.

2. They do not decide for themselves where to go and therefore lack the agency that is normally associated with migration.

3. They are assumed not to forge new social ties, which is seen as a crucial condition to be included in Charles Tilly's migration typology and which would distinguish migration from mobility. ${ }^{6}$

4. They do not so much join new communities as arrive and act as "invaders," even if they have an altruistic ("Samaritan") motive and selfimage and in that capacity hope "to contribute additional resources or benefits to the receiving society."

${ }^{4}$ For a historical typology of membership regimes, see U. G. Bosma, G. Kessler, and L. Lucassen, eds., Migration and Membership Regimes in Global and Historical Perspective (Leiden: Brill, 2013).

${ }_{5}$ Moch, Moving Europeans; D. Hoerder, Cultures in Contact: World Migrations in the Second Millennium (Durham, N.C.: Duke University Press, 2002); E. Ho, The Graves of Tarim: Genealogy and Mobility across the Indian Ocean (Berkeley: University of California Press, 2006); K. J. Bade, P. Emmer, L. Lucassen, and J. Oltmer, eds., The Encyclopedia of Migration and Minorities in Europe: From the I 7 th Century to the Present (New York: Cambridge University Press, 20I I); D. Hoerder, J. Lucassen, and L. Lucassen, "Terminologies and Concepts of Migration Research," in The Encyclopedia of European Migration and Minorities, ed. Bade et al., xxvii-xli.

6 Tilly, "Migration in Modern European History."

7 P. Manning, Migration in World History, 2nd ed. (Abingdon, U.K.: Routledge, 2013), 8. 
5. Finally, they do not fit the "subaltern, ${ }^{8}$ marginal man" or peasant image that has remained so dominant in most migration studies since the late nineteenth century.

The fundamental critique of the original Chicago school's interpretation of human mobility since the ig6os has not altered this image. In a way, the critique unintentionally has further aggravated the isolation of organizational migrants, due to the stress on the importance of individual agency and personal networks. ${ }^{9}$ The advantage is that we no longer conceive of migrants as passive particles pushed and pulled around, but rather acknowledge their agency. Furthermore, the botanical metaphor of uprootedness has been replaced by that of transplantation. ${ }^{10}$ These necessary spotlights on the importance of personal ("strong") ties and agency, however, did not lead to a fundamental paradigm shift pertaining to organizational migrants, since lower-class labor migrants remained the prime object of study.

To understand the blind spot for organizational migrants, the association with "invaders" (as the antithesis of the vulnerable migrant) is probably crucial, because most of the other four characteristics listed above also largely apply to other multiyear labor migrants, such as Mediterranean "guest workers" or Mexican "braceros" in the twentieth century. ${ }^{11}$ What distinguishes these labor migrants from organizational migrants is their low socioeconomic status. And this is where ideology weighs heavily.

Migration history as a distinct field of scholarship emerged in the

8 We use the term "subaltern" here more broadly than as defined by the (Gramscianinspired) Indian school of subaltern studies, meaning people with very limited means to resist repression and unequal treatment from above; see V. Chaturvedi, ed., Mapping Subaltern Studies and the Postcolonial (London: Verso, 2000); see also J. C. Scott, Weapons of the Weak: Everyday Forms of Peasant Resistance (New Haven, Conn.: Yale University Press, I985); and J. C. Scott, Domination and the Arts of Resistance: Hidden Transcripts (New Haven, Conn.: Yale University Press, I990).

9 C. Lesger, L. Lucassen, and M. Schrover, "Is There Life Outside the Migrant Network? German Immigrants in XIXth Century Netherlands and the Need for a More Balanced Migration Typology," Annales de Démographie Historique 2 (2002): 29-50.

10 As argued in R. J. Vecoli, "Contadini in Chicago: A Critique of the Uprooted," Journal of American History 5I, no. 3 (1964): 404-4I 7; D. Hoerder, Labor Migration in the Atlantic Economies: The European and North American Working Classes during the Period of Industrialization (Westport, Conn.: Greenwood Press, I984); J. Bodnar, The Transplanted: A History of Immigrants in Urban America (Bloomington: Indiana University Press, 1985); and C. Tilly, "Transplanted Networks," in Immigration Reconsidered: History, Sociology, and Politics, ed. V. Yans-McLaughlin (New York: Oxford University Press, I990), 79-95.

11 K. Calavita, Inside the State: The Bracero Program, Immigration, and the I.N.S. (New York: Routledge, I992). 
I960s and I970s as part of the "new social history" that demanded that the "people without history," both in Europe and in other parts of the world, would get their fair share of attention and rehabilitation. ${ }^{12}$ Workers, women, minorities, people in the (former) colonies, homosexuals, anarchists, and migrants all had in common that they had been marginalized, repressed, and exploited by capitalist, militarist, and patriarchal regimes, and historians and scholars from various disciplines (history, anthropology, sociology) became very interested in their voices and emancipation struggles, often with a Foucauldian gaze. ${ }^{13}$ Hence, social history, initially negatively defined as "history with the politics left out," 14 became a stronghold of the downtrodden and "subaltern," and developed a series of subspecialties, such as labor history, gender history, ethnic history, urban history, and last but not least migration history. From this perspective, organizational migrants, although also mostly consisting of ordinary men (soldiers) and sometimes women (such as schoolteachers), and often peasants themselves, were often seen as reactionary instruments in the hands of capitalist, imperialist, and repressive elites, and as such fit uncomfortably into the new social history wave. ${ }^{15}$ This is even more true for highly skilled "organizational migrants," who were primarily seen as members of the elite, such as corporate expatriates, missionaries, scholars, and diplomats. ${ }^{16}$

${ }^{12}$ E. R. Wolf, Europe and the People without History (Berkeley: University of California Press, I982).

13 See, for example, Scott, Weapons of the Weak; Scott, Domination and the Arts of Resistance. For a fundamental and provocative critique on postcolonial theory and the subaltern school in South Asian studies as a new form of Orientalism and cultural essentialism, see V. Chibber, Postcolonial Theory and the Specter of Capital (London: Verso, 2013).

${ }_{14}$ G. M. Trevelyan, English Social History (London: Longmans, Green, I945), 2.

${ }_{15}$ More recently this has been slowly changing, however, especially with respect to soldiers and sailors, as the recent collection of essays, S. Bhattacharya, ed., Towards a New History of Work (New Delhi: Tulika Books, 20I4), shows (see also M. Van der Linden, "The Promise and Challenges of Global Labor History," International Labor and Working-Class History 82 [fall 2012]: 65). This volume includes a separate section on "Soldiers and Sailors at Work" with contributions by A. Stanziani, M. van Rossum, and S. Dasgupta. Earlier inclusions of soldiers as migrants are to be found in U. Bosma, "Sailing through Suez from the South: The Emergence of an Indies-Dutch Migration Circuit, I8 1 5-1940," International Migration Review 4I, no. 2 (2007): 518-52 I. On sailors, see M. Van Rossum, Werkers van de wereld: Globalisering, arbeid en interculturele ontmoetingen tussen Aziatische en Europese zeelieden in dienst van de VOC, I600-1800 (Hilversum: Verloren, 2014).

${ }^{16}$ From the rg9os onward a number of social historians have acknowledged that organizational migrants should be studied within labor or colonial history, but this has not made a major impact in mainstream studies. See, for example, A. Lüdtke, "Alltagsgeschichte: Aneignung und Akteure: Oder, es hat noch kaum begonnen!" WerkstattGeschichte I 7 (1997): 83-92; A. Lüdtke, "Arbeiten und Kriegsführen: Soldatsein als (Kriegsarbeit)," Praxis Geschichte I2, no. 2 (I999): 32-35; J. Lucassen, and E.-J. Zürcher, "Conscription as 
Although labor history remained heavily focused on proletarian wage workers, ${ }^{17}$ since the I 990 os the influence of the new social history on the field of migration has broadened its horizon somewhat. Gradually the role of the state and other institutions has been recognized, reluctantly bringing slaves as well as merchants, artists, and migratory scholars into the picture. ${ }^{18}$ This was further stimulated by the emergence of global or world history as a field, in which itinerants were increasingly seen as crucial agents in the forging of global connections and empire. The growing interest in transnationalism and supranational organizations especially, ${ }^{19}$ but also the new imperial history, ${ }^{20}$ has

Military Labour: The Historical Context," International Review of Social History 43, no. 3 (I998): 405-419; U. Bosma, "European Colonial Soldiers in the Nineteenth Century: Their Role in White Global Migration and Patterns of Colonial Settlement," Journal of Global History 4, no. 2 (2009): 3 I 7-336; P. Pels, A Politics of Presence: Contacts between Missionaries and Waluguru in Late Colonial Tanganyika (Amsterdam: Harwood Academic Press, I999); U. Freitag and W. G. Clarence-Smith, eds, Hadhrami Traders, Scholars, and Statesmen in the Indian Ocean, I 750 os to I960s (Leiden: Brill, I997); M. Harper, ed., Emigrant Homecomings: The Return Movement of Emigrants, I600-2000 (Manchester: Manchester University Press, 2005); O. White, "Priests into Frenchmen? Breton Missionaries in Côte d'Ivoire, I896-I9I8," French Colonial History 8 (2007): I I I-I 2 I; M. Harper and S. Constantine, eds., Migration and Empire (Oxford: Oxford University Press, 2010).

17 Although not by definition: C. Tilly and C. Tilly, Work under Capitalism (Boulder, Colo.: Westview Press, I998).

18 J. Lucassen and L. Lucassen, eds., Migration, Migration History, History: Old Paradigms and New Perspectives (Bern: Peter Lang, I 997); D. Eltis, ed., Coerced and Free Migration: Global Perspectives (Stanford, Calif.: Stanford University Press, 2002); Hoerder, Cultures in Contact; see also M. Van der Linden and K. H. Roth, eds., Beyond Marx: Theorising the Global Labour Relations of the Twenty-first Century (Leiden: Brill, 20I4).

19 J. V. Beaverstock, "Transnational Elites in the City: British High-Skilled InterCompany Transferees in New York City's Financial District," Journal of Ethnic and Migration Studies 3I, no. 2 (2005): 245-268; R. L. Stirrat, "Mercenaries, Missionaries and Misfits: Representations of Development Personnel," Critique of Anthropology 28 (2008): 406-425; M. Barnett, Empire of Humanity: A History of Humanitarianism (Ithaca, N.Y.: Cornell University Press, 201 I ); M. Mazower, Governing the World: The History of an Idea (London: Penguin Press, 2012); P. Stamatov, The Origins of Global Humanitarianism: Religion, Advocacy, and Empire (Cambridge: Cambridge University Press, 2013).

20 F. Cooper and A. L. Stoler, eds., Tensions of Empire: Colonial Cultures in a Bourgeois World (Berkeley: University of California Press, I997); C. Hall, ed., Cultures of Empire: Colonisers in Britain and the Empire in Nineteenth and Twentieth Centuries: A Reader (Manchester: Manchester University Press, 2000); E. A. Buettner, Empire Families: Britons and Late Imperial India (Oxford: Oxford University Press, 2004); C. Hall and S. O. Rose, eds., Home with the Empire: Metropolitan Culture and the Imperial World (Cambridge: Cambridge University Press, 2006); N. B. Breyfogle et al., eds, Peopling the Russian Periphery: Borderland Colonization in Eurasian History (New York: Routledge, 2007); L. Chilton, Agents of Empire: British Female Migration to Canada and Australia, I860s-1930 (Toronto: University of Toronto Press, 2007); D. Feldman, "Jews and the British Empire c. I900," History Workshop Journal 63 (2007): 70-89; S. M. Miller, ed., Soldiers and Settlers in Africa, 1850-1918 (Leiden: Brill, 2009); S. Gordon, When Asia Was the World: Traveling Merchants, Scholars, Warriors, and Monks Who Created the "Riches of the East" (Cambridge, Mass.: Da Capo Press, 2009); 
helped to make the migratory behavior of its actors more visible. With Patrick Manning's typology of cross-cultural migration, organizational migrants (although not labeled as such) finally took center stage. ${ }^{21} \mathrm{His}$ fourfold distinction included "invaders," "sojourners," and "itinerants" alongside the more conventional "settlers."

In this article, we build on the conceptual contributions by Tilly and Manning and propose to take their typological contributions one step further. We combine the category of "career migrants" (Tilly) with those of "invaders," "sojourners," and "itinerants" (Manning), thereby merging elements of these four concepts into the concept of "organizational migrants." We define them as people (and their dependents) whose migratory behavior is primarily determined by the interests of the organization they have joined (voluntarily or forced). Moreover, we make a strong plea to include them systematically in the field of migration (and labor) studies, from both a historical and a social science perspective. As there are many different kinds of organizations that employ people and send them to different destinations in order to fight, negotiate, work, or help others, we decided to focus on two key institutions: ( I) the army and (2) NGOs and their precursors (religious and humanitarian organizations).

The reason for this choice is, first of all, that it offers us a chance to compare a state institution with a nonstate (civil society) one, but also because it enables us to compare on average elite migrants (missionaries and aid workers) with predominantly low-status migrants (soldiers) over a long period of time. Notwithstanding this wide spectrum, we will demonstrate a number of important commonalities shared by organizational migrants, irrespective of class background and time period, as well as some differences. Moreover, by including original quantitative data (in the case of soldiers) and qualitative examples (in the case of aid workers), we will illustrate their behavior as migrants. Finally, our specific comparative design follows Nancy Green's call not to concentrate on specific ethnic groups, but rather to take certain economic sectors or institutions as the unit of analysis. ${ }^{22}$

Harper and Constantine, Migration and Empire; R. Bickers, ed., Settlers and Expatriates: Britons over the Seas (Oxford: Oxford University Press, 2010); G. B. Magee and A. S. Thompson, eds., Empire and Globalisation: Networks of People, Goods and Capital in the British World, c. I850-I9 4 (Cambridge: Cambridge University Press, 2010).

21 P. Manning, Migration in World History (New York: Routledge, 2005); Manning, Migration in World History, and ed.

${ }_{22}$ N. L. Green, "The Comparative Method and Poststructural Structuralism: New Perspectives for Migration Studies," Journal of American Ethnic History 13, no. 4 (1994): 3-22. 


\section{Soldiers as Migrants}

As the historian Joshua Sanborn remarked in an article on the experiences of Russian soldiers during and immediately after World War I, migration history, like labor history, has treated soldiers badly. ${ }^{23}$ Their on average low-class status notwithstanding, soldiers may be termed the ultimate outcasts given their role in organized violence, aggression, and repression. But even this perspective on soldiers as instruments of the powerful is problematic. Encounters between soldiers and civilians do indeed often result in repression (of social movements), ${ }^{24}$ mass violence, rape, destruction, and religious and ethnic cleansing, but not always and not necessarily. Marjoleine Kars, for example, shows how European mercenaries in the Dutch colony of Berbice (part of Dutch Guiana) in the early I 760 s, instead of fighting, joined runaway slaves, thus turning into subalterns themselves. ${ }^{25}$ But even when soldiers just did their job, cross-cultural contacts were quite common. Although Kars does not make a link to migration history, she pleads for a much broader perspective on the social and cultural role of soldiers:

23 J. A. Sanborn, "Unsettling the Empire: Violent Migrations and Social Disaster in Russia during World War I," Journal of Modern History 77, no. 2 (2005): 290-324; and E.-J. Zürcher, "Introduction: Understanding Changes in Military Recruitment and Employment Worldwide," in Fighting for a Living: A Comparative History of Military Labour 1500-2000, ed. E.-J. Zürcher (Amsterdam: Amsterdam University Press, 2013), I I-4I. We should add that especially medieval and early modern historians have dealt with soldiers as migrants more systematically; see, for example, F. Redlich, The German Military Enterpriser and His Work Force: A Study in European Economic and Social History, 2 vols. (Wiesbaden: Steiner, 1964-1965); D. H. A. Kolff, Naukar, Rajput, and Sepoy: The Ethnohistory of the Military Labour Market in Hindustan, I 450-I850 (Cambridge: Cambridge University Press, I990); J. V. Farcy and A. Faure, La mobilité d'une génération de Français: Recherche sur les migrations et les déménagements vers et dans Paris à la fin du XIXe siècle (Paris: Institut National d'Études Démographiques, 2003); U. Tresp, Söldner aus Böhmen: Im Dienst deutscher Fürsten: Kriegsgeschäft und Heeresorganisation im I5. Jahrhundert (Paderborn: Schönigh, 2004). A category that has received somewhat more attention is that of "war brides"; see, for example, M. Höhn, GIs and Fräuleins: The German-American Encounter in I950s West Germany (Chapel Hill: University of North Carolina Press, 2002); S. Zeiger, Entangling Alliances: Foreign War Brides and American Soldiers in the Twentieth Century (New York: New York University Press, 2010); and M. Ward Crawford, K. K. Hayashi, and S. Shizuko, Japanese War Brides in America: An Oral History (Santa Barbara, Calif.: Greenwood, 2010).

${ }^{24}$ M. Van der Linden, "Preface," in Fighting For a Living: A Comparative History of Military Labour I500-2000, ed. E.-J. Zürcher (Amsterdam: Amsterdam University Press, 2013), 9 .

${ }_{25}$ The slave rebels, however, were very distrustful — and resentful —of the European soldiers and executed most of them (M. Kars, "Policing and Transgressing Borders: Soldiers, Slave Rebels, and the Early Modern Atlantic," New West Indian Guide 83, no. 3-4 (2009): 205 . 
Colonial historians have usually studied professional soldiers in their capacity of border enforcers, men sent overseas to maintain the cultural and legal divisions upon which colonial authority rested. Yet, in fact, soldiers regularly became key figures of connection as they straddled and crossed the very boundaries (literal and metaphorical) the authorities intended for them to maintain. Generally stationed on contested middle ground on the edges of empire, soldiers forged individual connections with indigenous peoples and slaves. Some of these contacts were considered routine and were accepted by the authorities. Others, however, struck hard at the very foundations of colonialism, challenging and violating European ideological premises with potentially explosive results. The mutiny in Berbice, carried out in the midst of a huge slave rebellion, represents one such threat. ${ }^{26}$

Her analysis fits quite well with the important observation by Joshua Sanborn, who argues that-almost by definition-in studies from below, analytical definitions tend to be determined by subjective views of those under study:

historians of migration have been even less receptive to the notion that soldiers can be analyzed as migrants than historians of armies have been to the idea that soldiers can be analyzed as murderers. For both sets of historians, the subjective context of social acts is the key. If soldiers believe they are not migrants because they think their social lives are suspended by war and because they plan to return home, then they are not migrants. If they believe that they are killing for the cause and if they know they are legally committed to killing rather than legally prohibited from doing so, then they are not murderers. ${ }^{27}$

As often with narrow definitions, we rob ourselves of comparative benefits that, as Sanborn and others have shown, are considerable in the case of soldiers and other organizational migrants. ${ }^{28}$ When we do not let ideology obstruct our view and focus on the spatial and social behavior of soldiers, while adopting the more social geographical perspective of scholars such as Wilbur Zelinsky, ${ }^{29}$ then this category turns out to be highly relevant for our understanding of human migrations and labor relations. And we do not mean this primarily in their func-

26 Ibid., I92.

27 Sanborn, Unsettling the Empire, 29I.

${ }^{28}$ For his point more generally, see Lucassen and Lucassen, Migration, Migration History, History.

29 Zelinksy, "The Hypothesis of the Mobility Transition." 
tion of killing, raping, and driving off others who then in turn become refugees. Taking soldiers seriously as migrants and workers forces us to realize that their migration patterns, cross-cultural experiences and exchanges, both at the destination and (after having returned) back home, bear crucial similarities to those of other, more conventional migrant workers.

In their recent book Broad Is My Native Land, Lewis Siegelbaum and Leslie Page Moch distinguish three contexts of desocialization and resocialization in which the experiences of soldiers and labor migrants are very much alike. ${ }^{30}$ As the world wars in the twentieth century "started with trains and not with trenches," we should first consider the phase of mobilization. This lifts (mostly, but not exclusively) ${ }^{31}$ men from their ordinary social context (family, village, urban neighborhood, workplace, gendered social networks) and puts them in a very different social context, becoming members of a new social formation of only men, often from very different parts of the country or empire, with different class, language, religious, and ethnic backgrounds, and with new and singular social rules, identities, and solidarities. In the barracks and at the front, they share this both exciting and frightening experience with their loved ones back home through letters and other means of communication, just like other migrants. ${ }^{32}$ The second context that makes them migrants is their contacts with civilians or enemy soldiers. These can be both peaceful and violent, but as the scholarship on military history shows, they are often much more intense and mutually dependent than most people realize-and much more than the army leadership would like. This was even the case, for example, in the trench warfare on the Western Front during World War I. ${ }^{33}$

As the experience of more recent wars (Korea, Vietnam, RussoAfghan, American-Afghan, and Iraq) illustrates, quite often those soldiers lucky enough to return alive have changed considerably, physically and mentally, and go through another process of desocialization and resocialization. Their experiences as soldiers can have both psy-

30 This tripartite distinction works less well in the early modern period. There the migration patterns of soldiers, particularly mercenaries (and sailors), were often multiphased, shifting in and out of service as well as shifting among cultural groups and settings.

31 In the course of the twentieth century, women also entered the army, whereas in the early modern period many women accompanied male soldiers as camp followers.

32 With the difference that the army, from the twentieth century onward, started censoring such letters, because such interchanges might lower morale or disclose strategic information.

33 Sanborn, "Unsettling the Empire," 29I. 
chological (including post-stress syndrome) and social dimensions, but what they have in common with other migrants is that upon returning, they look with very different eyes on the familiar but also narrow world that once encapsulated them..$^{34}$ Moreover, the positions of "tied migrants" or "military dependents" (partners, children) have changed as well. ${ }^{35}$

Finally, there are ample studies-especially those on empires-that show that not only are soldiers instrumental in extending the empire by moving the frontiers, but that many of them subsequently settle as farmers, often in very different ecological zones. These colonizations have a huge impact on the migrants themselves, who (as in the case of China, Japan, Russia, and the Ottoman empire) often have traveled over very long distances, but also on that of the native populations in these areas, for better or for worse. ${ }^{36}$

\section{HistoriogRAPHY}

Although, for the reasons sketched above, soldiers have not often been studied as labor migrants, their mobility has been widely mapped and studied by military historians, whose work is just waiting to be mined. ${ }^{37}$ Military historians, like their maritime colleagues (when it comes to the migratory experience of sailors), have been crucial in providing a wealth of data on labor migration. However, in contrast to "labor,"

${ }^{34}$ G. Rosen, "Nostalgia: A 'Forgotten' Psychological Disorder," Psychological Medicine 5, no. 4 (1975): 340-354; B. Gersons and I. Carlier, "Post-traumatic Stress Disorder: The History of a Recent Concept," British Journal of Psychiatry I6I (I 992): 742-748.

35 T. J. Cooke and K. Speirs, "Migration and Employment among the Civilian Spouses of Military Personnel," Social Science Quarterly 86, no. 2 (2005): 343-355; P. E. Wolgin and I. Bloemraad, "'Our Gratitude to Our Soldiers': Military Spouses, Family Re-Unification, and Postwar Immigration Reform," Journal of Interdisciplinary History 4I, no. I (2010): 3I, 53 .

${ }^{36}$ For extensive analyses of the Russian, Chinese, and Japanese cases, see the contributions by Willard Sunderland; Adam McKeown; and Leo Lucassen, Osamu Saito, and Ryuto Shimada in J. Lucassen and L. Lucassen, eds., Globalising Migration History: The Eurasian Experience (I6th-2 Ist Centuries) (Leiden: Brill, 2014). See also P. Perdue, China Marches West: The Qing Conquest of Central Eurasia (Cambridge, Mass.: Belknap Press of Harvard University Press, 2005).

37 Exceptions are V. Ware, Military Migrants: Fighting for YOUR Country (London: Palgrave Macmillan, 20I2); and R. S. Fogarty, Race and War in France: Colonial Subjects in the French Army, 1914-1918 (Baltimore: Johns Hopkins University Press, 2008), but their angle is soldiers in the British and French army with a colonial background, not soldiers as such. See also N. Arielli and B. Collins, eds., Transnational Soldiers. Foreign Military Enlistment in the Modern Era (Houndmills: Palgrave Macmillan, 2013). 
they seldom use "migration" as an organizing and sensitizing concept. And even when they do so, these studies have trouble becoming incorporated into mainstream migration history, thus leaving the splendid isolation of the two fields intact.

In the last decade this has slowly begun to change for the better. In 2008 , Jochen Oltmer published a useful migration typology that included soldiers. ${ }^{38}$ At first sight, Oltmer's approach does not seem to be relevant, as he primarily focuses on forced migrations, and thus on people who are forced to flee because of warfare. He does not, however, leave it at that but treats soldiers both as forces that "move" others and as employees who are moved due to the orders they receive. $\mathrm{He}$ therefore includes soldiers as forced migrants within the context of military labor markets. This labor dimension of temporary, multiannual migrants has proven very fruitful to bridge the gap between military and migration history. A similar approach can be found in the crosscultural migration typology of Jan and Leo Lucassen, in which soldiers and sailors are systematically studied as exponents of "temporal multiannual migrations." ${ }^{39}$ An important step forward is the previously mentioned approach that Siegelbaum and Moch take to the migratory process of soldiers. Using the case of Russia in the twentieth century, they analytically distinguish three phases: (I) mobilization/leaving home, (2) active service, and (3) demobilization/return. Stimulated by the work of Sanborn, for each phase they convincingly show the similarities with other migrants from a (de/re) socialization perspective. ${ }^{40}$

In the burgeoning historiography, the stress is clearly on the first two phases. Most studies deal with recruitment, size, numbers, wages, labor relations, spatial deployment, composition, mortality, and productivity. However, housing, billeting of troops, local contacts, and sociocultural interactions are also excellent units of analysis that bring soldiers into migration studies. In recent decades these topics have been studied intensely, making it possible to quantify soldiers as migrants both in Europe and Asia in the last half millennium. ${ }^{41}$ As William Tatum

\footnotetext{
38 J. Oltmer, "Migration, Krieg und Militär in der Frühen und Späten Neuzeit," in Krieg, Militär und Migration in der Frühen Neuzeit, ed. M. Asche et al. (Münster: LIT, 2008), 37.

39 J. Lucassen and L. Lucassen, "The Mobility Transition Revisited, I500-1900: What the Case of Europe Can Offer to Global History," Journal of Global History 4, no. 4 (2009): 347-377.

40 L. Siegelbaum and L. Page Moch, Broad Is My Native Land: Repertoires and Regimes of Migration in Russia's Twentieth Century (Ithaca, N.Y.: Cornell University Press, 2014), chap. 5 .

41 Lucassen and Lucassen, "The Mobility Transition Revisited"; J. Lucassen and L. Lucassen, "The Mobility Transition in Europe Revisited, I 500-1900: Sources and Meth-
} 
describes in his analysis of eighteenth-century British army studies, we still witness the aftermath of the incorporation of new social history agendas and analytical tools into the "new military history" from the I970s onward. Although this has resulted in more attention paid to the social history of armies and the impact of war on society-be it at home or abroad-Tatum is critical of the way it overemphasizes the lack of agency at the lower levels of the institution. Instead, he suggests that a division between history of war and history of the army (leaving the combat out) will open the field to historians from other subfields. ${ }^{42}$

These recent initiatives link up quite well with the more international and comparative-oriented projects. A showcase is the dossier in the International Review of Social History (I998) (3) $^{4}$ and the long-term research project "Fighting For a Living." 44 Like the volume on migration and the military by Matthias Asche and others from 2008, as well as a recent overview of transnational soldiers, ${ }^{45}$ these programmatic studies explicitly connect war, military labor markets, and migration for the early modern and modern periods, ${ }^{46}$ and make clear that soldiersboth footmen and officers-were labor migrants for whom the military was a way to earn a living, one that involved moving around, often over considerable distances. The often impressive spatial mobility was reduced somewhat with the rise of standing armies and conscription in the late eighteenth and nineteenth centuries, but in the latter case, as soon as wars broke out, massive armies often crossed international

ods," IISH Research Papers (Amsterdam: International Institute of Social History No. 44 20IO); and Lucassen and Lucassen, Globalising Migration History. See also B. Rogaly and B. Taylor, “'They Called Them Communists Then ... What D'You Call 'Em Now?... Insurgents?' Narratives of British Military Expatriates in the Context of the New Imperialism," Journal of Ethnic and Migration Studies 36, no. 8 (2010): I335-135I; Gersons and Carlier, "Post-traumatic Stress Disorder"; and Bhattacharya, Towards a New History of Work.

${ }_{42}$ William P. Tatum III, "Challenging the New Military History: The Case of Eighteenth-Century British Arm Studies," History Compass 4 (2006): 2, 5, 9-10.

${ }^{43}$ Lucassen and Zürcher, "Conscription as Military Labour"; J. Lucassen and E. J. Zürcher, "Introduction: Conscription and Resistance: The Historical Context," in Arming the State: Military Conscription in the Middle East and Central Asia I775-I925, ed. E. J. Zürcher (London: I. B. Tauris, I999), I-20.

${ }^{44}$ https://projects.iisg.nl/web/fighting-for-a-living.

45 Arielli and Collins, Transnational Soldiers.

${ }^{46}$ M. Asche, "Krieg, Militär und Migration in der Frühen Neuzeit: Einleitende Beobachtungen zum Verhältnis von horizontaler und vertikaler Mobilität in der kriegsgeprägten Gesellschaft Alteuropas im I 7. Jahrhundert," in Krieg, Militär und Migration in der Frühen Neuzeit, ed. M. Asche et al. (Münster: LIT Verlag, 2008), i I-36. See also B. R. Kroener, "Krieg und Karriere: Geographische Mobilität als Voraussetzung sozialen Aufstiegs in der militärischen Gesellschaft des I 7. Jahrhunderts," in Über die trockene Grenze und über das offene Meer. Binneneuropäische und transatlantische Migrationen im I8. und 19. Jahrhundert, ed. M. Beer and D. Dahlmann (Essen: Klartext, 2004), 45-66. 
or internal imperial borders and were exposed not only to bullets and bombs, but also to other cultures. ${ }^{47}$

In the nineteenth and early twentieth centuries, soldiers were also central to the imperial project, as Ulbe Bosma has argued convincingly. ${ }^{48}$ He calculated that in the course of the nineteenth century, at least 6.5 million European soldiers left for the colonies, predominantly in Asia (especially in British India and the Dutch East Indies). He also shows that there are ample reasons to consider them both as migrants and settlers, because many of them settled for good as "white labor" in the colonies. One of the reasons they have been ignored for so long, according to Bosma, is that in the era heralded as the breakthrough of "free migration" ( $1850-$ I940), soldiers were still predominantly perceived as people who were more or less forced and pressed into service, or at least as migrants without the freedom to choose their destination. The increase in the number of European soldiers sent to other continents, therefore, coincided with the rise of the idea that coerced (indentured) migration was typical for non-Western "races," especially Chinese and Indians. ${ }^{49}$ Another reason these huge numbers of soldiermigrants have been left out of the migration story is that they were assumed to be isolated from the local population and their stay temporary. Also here Bosma's work shows otherwise, and his analysis fits within a wider stream of literature by military historians working on Europe. Especially in the case of mercenaries, garrisons, and long-term occupation armies, soldiers fought very little and had plenty of time to interact with the local population in a more peaceful way. The billeting of foreign (mercenary) soldiers, especially Swiss and Scottish, was quite normal in early modern cities and created numerous contact zones in which cross-cultural exchanges took place. ${ }^{50}$ In I 70 I, some fifty-four thousand Scottish soldiers were serving in France, the Dutch Republic, Spain, and other European states, whereas during the entire eighteenth century, more than three hundred thousand Swiss mercenaries worked

47 Although we refer to soldiers as men, we are aware of the practice of women disguising themselves as men to join the army. According to F. Easton, female soldiering was well tolerated and rewarded in the early modern plebeian world of work. F. Easton, "Gender's Two Bodies: Women Warriors, Female Husbands, and Plebeian Life," Past and Present r 80 (2003): I 43 .

48 Bosma, "European Colonial Soldiers in the Nineteenth Century."

49 Ibid., 334; see also A. McKeown, Melancholy Order: Asian Migration and the Globalization of Borders (New York: Columbia University Press, 2008).

50 Murdoch 201 I; Czouz-Tornare 20 I I; Kroll 20I I. (For full references of these entries see Bade et al., The Encyclopedia of Migration and Minorities in Europe.) 
abroad.$^{51}$ Moreover, many mercenaries did not return after they retired but instead stayed on, often marrying local women. Thousands of Scots were thus integrated into local German, Swedish, Dutch, and Russian societies, while partly maintaining their own brand of faith in the Scottish Kirk. ${ }^{52}$ Another case study shows how soldiers in eighteenthcentury Göttingen who wanted to integrate into local society had a clear advantage over other migrants, thanks to the contacts and social networks they had built during their stay in the barracks. ${ }^{53}$

With the emergence of draft armies and modern warfare, one might expect that contacts between soldiers and civilians would be greatly diminished. As recent studies on World Wars I and II, as well as on postwar occupation armies, have shown, however, this is not the case. ${ }^{54}$ The pioneering work of Maria Höhn and others has shown that the impact of the many American bases in postwar Germany, for example, was much greater than is often assumed. At the local level, Americans frequently interacted with German women and men in bars, cafés, and shops, but also in towns and villages where many soldiers rented housing, which led to thousands of marriages and mixed offspring. Furthermore, at the collective level the American presence, as symbol of modernity (including looser sexual norms) and the new consumption culture (Hollywood movies, popular music), deeply influenced German society. It is therefore understandable that conservative circles in Germany were deeply worried about what they perceived as an attack on traditional religious and social norms and values. ${ }^{55}$ One could, of course, argue that the cultural revolution of the i96os and I970s would have made its influence felt anyway, but it is an undisputed fact that the interpersonal contacts with American soldiers, black and white, socialized hundreds of thousands of Germans in a much more direct and intensive way-contacts that, moreover, led to the emigration of many thousands of German women who married American GIs and often accompanied their husbands when their tours of duty came to an end. As Goodman describes in her article "Only the Best British Brides," in the case of US servicemen stationed in Britain during the Cold War,

\footnotetext{
51 Czouz-Tornare 20I I: 7ro. (For a full reference, see Bade et al., The Encyclopedia of Migration and Minorities in Europe.)

52 Murdoch 201 I: 669. (For a full reference see Bade et al., The Encyclopedia of Migration and Minorities in Europe.)

53 R. Pröve, Stehendes Heer und städtische Gesellschaft im I8. Jahrhundert: Göttingen und seine Militärbevölkerung I 713-1756 (Paris: Deutsches Historisches Institut, I995).

54 Sanborn, "Unsettling the Empire," 29r. See especially his critique on John Keegan.

55 Höhn, GIs and Fräuleins.
} 
this resulted in the engagement of government agencies, army generals, and the Women Volunteers Service in making sure these interactions would be with the "good-type" (that is, social class) girl..$^{56}$

This brings us to the third phase distinguished by Siegelbaum and Moch in their book: demobilization and returning home. One of the most glaring examples is the social and political effect that returning African American soldiers had on American society, ${ }^{57}$ having encountered for the first time in their lives a non-racially segregated society. Although racism was not absent from German communities surrounding American bases, it was largely imported by the American army itself, which upheld discriminatory measures within its ranks well into the I960s. ${ }^{58}$ Notwithstanding the occurrence of discrimination against black GIs by Germans (landlords, bar owners, and so on), their German tour of duty made them realize that being treated as second-rate citizens, or worse, was not normal. Or, in the prophetic words of the distinguished African American writer William Gardner Smith in I947: After being treated as social equals, Black American GIs would "never go back to the old way again." 59 And this holds true not only for those who had liberated Europe from Nazi rule, but also for the millions of African-American soldiers who were based in Germany in the decades to follow. The impact of the German experience of returning black soldiers on the slowly unfolding civil rights movement in the US was also recognized and discussed at the time, as has been demonstrated by an analysis of the influential black weekly Ebony and similar periodicals and newspaper in the postwar period. ${ }^{60}$ In the case of the African American airmen stationed in Britain during the Cold War

56 G. Goodman, “'Only the Best British Brides': Regulating the Relationship between US Servicemen and British Women in the Early Cold War," Contemporary European History I 7, no. 4 (2008): 49 I.

57 P. Goedde, "Gender, Race and Power: American Soldiers and the German Population," in The United States and Germany in the Era of the Cold War, I945-1990: A Handbook, ed. D. Junker et al. (Cambridge: Cambridge University Press, 2004), 5I 7. She writes that black GIs made up 6 percent of the American forces in Germany, which in the entire postwar period (I945-I990) would have involved almost one million individuals (for total numbers, see M. Höhn and S. Moon, eds., Over There: Living with the U.S. Military Empire from World War Two to the Present (Durham, N.C.: Duke University Press, 2010). Also see, on the First World War, where African American soldiers decided to return to (imagined?) race-free Paris to live there, N. L. Green, The Other Americans in Paris: Businessmen, Countesses, Wayward Youth, I880-I94I (Chicago: University of Chicago Press, 2014), I 8.

58 Höhn, GIs and Fräuleins, IO2.

${ }_{59}$ M. Höhn and M. Klimke, A Breath of Freedom: The Civil Rights Struggle, African American GIs, and Germany (New York: Palgrave MacMillan, 2010), I.

60 A. Lubin, Romance and Rights: The Politics of Interracial Intimacy, 1945-1954 (Jackson: University Press of Mississippi, 2005), I Io. 
in Goodman's study, there was also a fear of mixed-race relationships and "black babies." ${ }^{11}$ Similar issues came into question with respect to the "war brides" of American soldiers returning from countries such as Japan and Korea, who fell under the Chinese Exclusion Acts. Wolgin and Bloemraad suggest that the reforms necessary for the return of these soldiers with their families caused a shift from race-based to family-reunification policies in the US since $1965 .{ }^{62}$

\section{Mainstreaming}

As always, it takes time before specialist studies influence mainstream narratives and conceptualizations. To illustrate this we looked at four major reference works in the field of migration studies: three migration encyclopedias from the period I995-20I3 and Dirk Hoerder's encompassing monograph from 2002.

Although attention to soldiers in these three works of course depends on the (often implicit) definitions and concerns of the editors, they reflect trends in the broader historiography. The good news is that interest in soldiers as migrants is clearly on the rise, with the most recent Cambridge encyclopedia as a provisional culmination point. This is not so much reflected by the number of pages discussing soldiers as (labor) migrants, but by the broadening range of historical experiences. This becomes clear when we compare Dirk Hoerder's magnum opus with the collective encyclopedia by Klaus Bade et al. Hoerder discusses soldiers largely in relation to the Middle Ages and the early modern period (starting with the Crusades), and limits the study of soldiers in the modern period to colonial contexts. ${ }^{63}$ Hoerder does touch upon soldiers in the twentieth century, ${ }^{64}$ but less systematically and with a predilection for prisoners of war and demobilized soldiers. Surprisingly, given his focus on intercultural contacts, he barely discusses the contact zones between soldiers and civilians. This aspect is explored in greater depth in the 20 I I Cambridge encyclopedia by Bade et al., espe-

61 This racial fear was also used for anti-US communist propaganda. Goodman stresses that the fact that these soldiers served during peacetime made them more vulnerable to negative (political) stereotypes, whereas they were not solely "sacrificing." Goodman, "'Only the Best British Brides," 499-500.

62 Wolgin and Bloemraad, "Our Gratitude to Our Soldiers," 28-30.

${ }^{63}$ Hoerder, Cultures in Contact, 278-2 79, and for Russia also later (316). On the colonial context, see 423-425.

${ }^{64}$ Ibid., 450-453. 
TABLE I. Explicit attention to soldiers as migrants in three recent seminal publications in the field of migration history ( I995-20 I I)

\begin{tabular}{lccrc}
\hline & $\begin{array}{c}\text { Number of entries } \\
\text { with explicit reference } \\
\text { to soldiers as migrants }\end{array}$ & $\begin{array}{c}\text { Number of pages } \\
\text { on which soldiers as } \\
\text { migrants are mentioned }\end{array}$ & $\begin{array}{c}\text { Total } \\
\text { number } \\
\text { of entries }\end{array}$ & $\begin{array}{c}\text { Total } \\
\text { number } \\
\text { of pages }\end{array}$ \\
\hline $\mathrm{CSWM}^{\mathrm{a}}$ & $0[0 \%]$ & $0[0 \%]$ & 95 & 560 \\
$\mathrm{CC}^{\mathrm{b}}$ & $3[1.7 \%]^{\mathrm{c}}$ & $31[5.3 \%]^{\mathrm{d}}$ & 169 & 582 \\
$\mathrm{EMME}^{\mathrm{e}}$ & $16[7.3 \%]$ & $39[7.2 \%]$ & 220 & $538^{\mathrm{f}}$ \\
$\mathrm{EGHM}^{\mathrm{g}}$ & 0 & 0 & $>600$ & $2763^{\mathrm{h}}$ \\
\hline
\end{tabular}

a R. Cohen, The Cambridge Survey of World Migration (Cambridge: Cambridge University Press, I995).

b Hoerder, Cultures in Contact.

c "Crusaders."

d As the book has no entries, but a very detailed table of contents, we took the different paragraph titles within chapters as point of departure.

e See the entries by Jordi (222ff.); Müller (225ff.); Brochmann (270); Boeck (296ff.); Pelzer (374ff.); Schubert (397ff.); Michels (45off.); Esser (456ff.); Smeets (572ff.); Oltmer (625ff.);

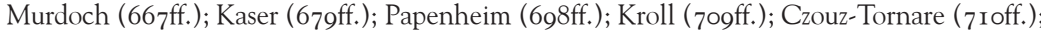
Bossenbroek (743ff.). For full references of the entries, see Bade et al., The Encyclopedia of Migration and Minorities in Europe.

f We only counted the "Groups" entries (pp. 2 ro-747).

g I. Ness, ed., The Encyclopedia of Global Human Migration (Chichester: Wiley-Blackwell, 2013). 5 volumes.

h Volumes 2-5 (for our calculations, we left out volume I, on prehistory).

cially in entries that deal with war brides ${ }^{65}$ and the military occupation of postwar East and West Germany by Christian Müller, who gives an excellent overview of the manifold contacts between American and Russian soldiers and German citizens in the postwar period. Based on his own work as well as that of Maria Höhn and others, he shows that the idea of isolation should be rejected ${ }^{66}$ The most recent encyclope-

65 Entries by Brochmann and Esser. For full references of the entries, see Bade et al., The Encyclopedia of Migration and Minorities in Europe.

66 C. T. Müller, US-Truppen und Sowjetarmee in Deutschland: Erfahrungen, Beziehungen, Konflikte im Vergleich (Paderborn: Ferdinand Schöningh Verlag, 20I2); Höhn, GIs and Fräuleins. See also P. Goedde, GIs and Germans: Culture, Gender, and Foreign Relations, 1945-1949 (New Haven, Conn.: Yale University Press, 2003). It is interesting that there has been attention to German GIs as migrants already from the mid-I98os onward, but that migration scholars have been very slow to pick this up. Wolgin and Bloemraad, "'Our Gratitude to Our Soldiers,"” 33-34. 
dia by Ness, in contrast, has one entry titled "Soldiers and Citizens," but here soldiers are only treated as producing migration. ${ }^{67}$

\section{Typology and Quantitative Data}

To study soldiers as migrants, Patrick Manning's definition of cross-cultural migration is most useful. Manning developed this concept in his 2005 reference book Migration in World History. ${ }^{68}$ One of the distinct forms of cross-cultural migration is people who move as "invaders" and not so much join as take over new societies, imposing their rule and thus forging social change. Although we largely agree with this position, we also would like to test these assumptions and thus "unpack" the invader category more thoroughly. Let us first focus on the numerical importance of soldiers as migrants compared to other cross-cultural forms of migration. How many people have been active as soldiers, and - in earlier times - as people who moved with soldiers-wives, children, prostitutes, peddlers, and musicians? In military history these groups are known as "the army train," so vividly portrayed by Bertolt Brecht in his famous antimilitarist play "Mutter Courage und ihre Kinder" (1939), situated in Germany's Thirty Years' War. ${ }^{69}$ To make the numerical importance of soldiers as cross-cultural migrants visible, restricting ourselves to those soldiers who were active in other countries in Europe's past five centuries, we used a typology developed in 2009 to define and measure cross-cultural migrations worldwide, with the aim to measure how many individuals in a certain geographical space (a region, a country, a continent) experienced at least one crosscultural move in their life. ${ }^{70}$ The method first requires that research-

67 See the entry of Bernazzoli in I. Ness, ed., The Encyclopedia of Global Human Migration (Chichester: Wiley-Blackwell, 2013).

68 Manning, Migration in World History; P. Manning, "Cross-Community Migration: A Distinctive Human Pattern," Social Evolution and History 5, no. 2 (2006): 24-54; Manning, Migration in World History, and ed.

${ }^{69}$ For studies on the army train see, for example, K. Hagemann and R. Pröve, eds., Landsknechte, Soldatenfrauen, und Nationalkrieger: Militär und Geschlechterordnung im historischen Wandel (Frankfurt am Main: Campus Verlag, I998).

70 Lucassen and Lucassen, "The Mobility Transition Revisited;" Lucassen and Lucassen, "The Mobility Transition in Europe Revisited;" J. Lucassen and L. Lucassen, "From Mobility Transition to Comparative Global Migration History," Journal of Global History 6, no. 2 (201 I ): 299-307; Lucassen and Lucassen, Globalising Migration History; L. Lucassen et al., "Cross-Cultural Migration in Europe I90I-2000: A Preliminary Estimate," IISH Research Papers (Amsterdam: International Institute of Social History, 2014). 
ers define the geographical and temporal unit of analysis, in this case Europe from 1500 to 2000 , and measure those who:

I. Left the unit (emigration).

2. Entered the unit (immigration).

3. Moved internally to cities to settle (to cities).

4. Moved internally to land (colonization).

5. Moved as seasonal migrants and returned within a year (seasonal).

6. Moved as temporary labor migrants and stayed longer than a year (temporal multiannual).

Soldiers and sailors have been subsumed in the last category and, in order to avoid double counts, have been left out of the immigration and emigration categories. Figure I shows the importance of "temporal multi-annual" migrations in Europe since I500, the bulk of which regards soldiers. In most periods, soldiers constitute over half the total number of cross-cultural migrants in Europe, with their share reaching an all-time high in absolute and relative numbers in the first half of

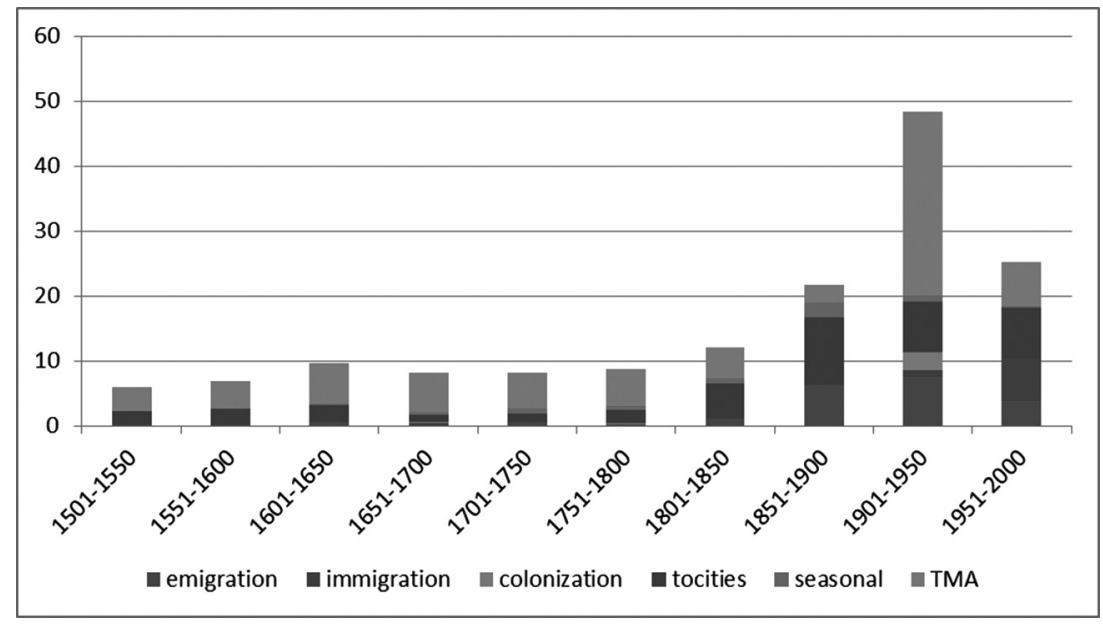

FigURE I. Total cross-cultural migration rates (\%) in Europe (excluding Russia) ( 50 I-2000). Source: L. Lucassen et al., "Cross-cultural Migration in Europe I90I-2000: A Preliminary Estimate," IISH Research Papers (Amsterdam: International Institute of Social History, 20 I 4), I I 4 . Note: For the twentieth century we did leave out people who moved to cities within European nation-states, because by that time most nation-states had become culturally so homogenous that the internal move from village to city did not imply a fundamental cultural change. 
the twentieth century due to the two World Wars. But numbers also remain high in the latter part of the twentieth century, notwithstanding the absence of war (except in Yugoslavia in the r99os), because of the already mentioned contingents of American and Russian troops. ${ }^{71}$ In Tables 2 and 3 we have summarized the main wars and occupations

TABLE 2. Total number of soldiers (I9OI-I950) (millions)

\begin{tabular}{lcccc}
\hline & $\begin{array}{c}\text { European } \\
\text { soldiers in } \\
\text { other European } \\
\text { countries } \\
\text { (millions) }\end{array}$ & $\begin{array}{c}\text { Non-European } \\
\text { soldiers in } \\
\text { Europe from } \\
\text { the colonies }\end{array}$ & $\begin{array}{c}\text { Non-European } \\
\text { soldiers in Europe } \\
\text { from the US and } \\
\text { (former) UK } \\
\text { dominions }\end{array}$ & Total \\
\hline World War I & 49.8 & 0.733 & 2 (US) and 0.952 & 53.48 \\
World War II & 33.5 & $?$ & 8 (US) and 0.864 & 42.4 \\
Postwar & 1.5 & & 2 (US) & 3.5 \\
$\begin{array}{l}\text { Occupations } \\
\text { Colonial wars }\end{array}$ & 0.1 & & & 0.1 \\
Subtotal & 85 & 0.77 & 14 & 99.8 \\
\hline
\end{tabular}

Source: Lucassen et al., "Cross-cultural Migration in Europe I90I-2000.”

TABLE 3. Total number of soldiers and dependents in Europe (I95 I-2000)(millions)

\begin{tabular}{|c|c|c|c|c|}
\hline & $\begin{array}{l}\text { Western } \\
\text { Europe }\end{array}$ & $\begin{array}{l}\text { Eastern } \\
\text { Europe }\end{array}$ & $\begin{array}{l}\text { Non-European } \\
\text { soldiers in Europe } \\
\text { from the US and } \\
\text { (former) UK } \\
\text { dominions }\end{array}$ & Total \\
\hline $\begin{array}{l}\text { Intra-European wars } \\
\text { (Yugoslavia) }\end{array}$ & 0.08 & & 0.02 (US) & 0.1 \\
\hline $\begin{array}{l}\text { Extra-territorial } \\
\text { military bases }\end{array}$ & 1.4 & 7.6 & 13 (US) & 22 \\
\hline Colonial wars & 2.135 & - & & 2.135 \\
\hline $\begin{array}{l}\text { Extra-European wars } \\
\text { and peacekeeping } \\
\text { (Korea, Lebanon, etc.) }\end{array}$ & $\begin{array}{c}0.041 \\
\text { (Korea) }\end{array}$ & & & 0.041 \\
\hline Total & 3.66 & 6.8 & 13.02 & 24.3 \\
\hline
\end{tabular}

Source: Lucassen et al., "Cross-cultural Migration in Europe I90I-2000."

${ }^{71}$ Höhn and Moon, Over There. 
in which European soldiers and soldiers from other continents active in Europe were involved in the twentieth century.

Apart from the fact that these 25 million soldiers (mainly men, but also women and families, especially in the case of post-World War II military bases) moved over long distances, many of them also engaged in all kinds of contact with locals that influenced their cultural knowledge and sometimes worldviews, which many of them also infused into their home communities.

What makes soldiers stand out as organizational migrants is that their agency as migrants and workers is quite limited due to the strict discipline, nonnegotiable chain of command, and severe sanctions on breaching the rules of the military (with the death penalty for desertion as the most extreme example). In this sense their position bears some resemblance to that of indentured workers and slaves in terms of the coercive elements of labor relations. Additionally, most of the soldiers were low skilled and as such had little power to negotiate better working conditions. At first sight, therefore, soldiers seem to be the antithesis of corporate expatriates and aid workers, but as we will show in the second part of this article, the two groups do share a number of important systemic (organizational) characteristics.

\section{Aid Workers as Migrants ${ }^{72}$}

In the I958 novel The Ugly American authors William J. Lederer and Eugene Burdick describe a fictional campaign for people to apply for overseas duty: "Now I know what's on your minds. At least on the minds of some of you,' Joe said jovially. 'Your social life. O.K., let's talk about it. You'll have to work among foreigners, but we don't expect you to love 'em just because you work among 'em. I don't care where you go to work for Uncle Sammy, you'll be living with a gang of clean-cut Americans. And a lot of 'em are single people, so you won't be lonesome if you're not married." "73

In the "factual epilogue" to their controversial book, Lederer and

72 Because this paragraph focuses on the second half of the twentieth century, most attention is being paid to aid workers. However, religiously motivated aid workers and religious NGOs are included, and the importance of contacts with the relatively small group of remaining missionaries is addressed (as predecessors in the field, they are often consulted for their historical and local knowledge).

73 W. J. Lederer and E. Burdick, The Ugly American (New York: W. W. Norton and Company, i 958), 69. 
Burdick take a critical stance toward the experiences of Americans in Southeast Asia in the context of Cold War politics. They suggest that, in contrast to the prevailing practice, Americans should be willing to risk their comfort and health, go equipped, speak the language of the country of their assignment, and be more expert in its problems than the natives. All in all they should be willing "to pay the human price." ${ }^{74}$ As will become clear from our discussion of the historiography on (religiously motivated) aid workers, the latter characteristic is one of the main reasons why this group has not yet been studied as migrants. Just like soldiers, aid workers tend to be excluded from mainstream migration studies because of the supposed temporary nature of their move (assumption I), their lack of agency with regard to their choice of destination (assumption 2), and the contrasting views with regard to the new social ties they forge (ranging from "going native" to isolating themselves in the "Aidland" bubble) (assumption 3). But more importantly, the fact that they do not so much join new communities but have other motives, be they altruistic or imperialist, for migration distinguishes them from "real migrants" (assumption 4). As Manning argues in his discussion of migration in world history, one possible motive for migration is "Samaritan": "the migrant may hope to contribute additional resources or benefits to the receiving community. This motivation is perhaps, most easily seen for religious missionaries, who move to new communities with the desire of spreading their faith, but can also be seen for people who move to spread new technologies." 75

In the case of present-day, non-religious aid workers, the term "humanitarian" seems to express a similar attitude. This motive for migration best suits the sojourner category in Manning's typology of cross-community migration, distinguishing them from settlers, itinerants, and invaders. He defines sojourners as "those moving to a new community, usually for a specific purpose [our italics] with the intention of returning to their home community." 76

In a widely cited 1977 article on expatriate communities, Erik Cohen distinguishes four types of "voluntary temporary migrants, mostly from affluent countries" on the basis of their purposes: business, mission, teaching, and leisure. Foreign aid personnel, representatives of foreign non-profit organizations, and missionaries are lumped together

\footnotetext{
74 Ibid., 240.

75 Manning, Migration in World History, 8.

76 Ibid., 9 (our italics).
} 
in the category of "mission." " Although his distinction is somewhat arbitrary, because it also includes diplomatic and government representatives and military personnel stationed abroad ${ }^{78}$ while excluding "teaching" as a form of mission, it underlines the importance of organizations in shaping the experiences of such migrants.

The "voluntary" and "sacrificial" nature of aid workers' migration seems to be the major reason to exclude them from mainstream migration and labor studies. As mentioned in the previous paragraph, the fact that the fields of migration and labor history developed as part of the new social history in the I96os and I970s results in a focus on repressed groups with limited agency and who are dependent on market forces. Aid work does not fit this image, as it is often associated with volunteering. In a recent volume on the everyday lives of development workers, however, Fechter and Hindman make a plea to include aid within the anthropology of work. They emphasize the unclear boundary between career aid workers, student volunteers, retirees on working vacations, and religious groups engaged in outreach, whereas a "conflicted relationship [exists] between heeding the call to engage in forms of sacrifice and emotional labor as part of the caring aspect of aid and keeping their career desires and their own family's financial needs in mind." 79

Moreover, in his article "Mercenaries, Missionaries, and Misfits" on the existing stereotypes of aid workers, Roderick Stirrat criticizes the idea that "besides those motivated by money or by mission, there are also those who enter the world of development because they are misfits in their home country," and therefore are not taken seriously as employees. ${ }^{80}$ In addition, development aid is often associated with skilled professionals who move from rich to poor countries and thus with aid workers who take a hegemonic position vis-à-vis subaltern groups (assumption 5). From the I970s and I980s onward, this has resulted in heated debates in the fields of anthropology and develop-

77 E. Cohen, "Expatriate Communities," Current Sociology 24, no. 3 ( I 977): 6.

78 Note that many soldiers often also view their activities abroad as a form of help to (re)establish democracy, fight religions and ideologies that they perceive as wrong and dangerous, or protect people against aggression and natural disasters. That those to whom this "help" is directed may think otherwise does not make these motives less relevant or sincere to the organizational migrants themselves.

79 Our italics. A.-M. Fechter and H. Hindman, eds., Inside the Everyday Lives of Development Workers: The Challenges and Futures of Aidland (Sterling, Va.: Kumarian, 20 I I), 7.

80 Stirrat, "Mercenaries, Missionaries and Misfits," 4 I 8 . However, their activities do count as work as defined by Tilly and Tilly, Work under Capitalism, 22-23: "any human effort adding value to goods and services, no matter whether the performers like or detest the effort." 
ment studies with regard to the moral and ideological dimensions of development. Especially from the rg6os onward the political, economic, or religious agenda that determines foreign aid and donorhost relationships was labeled imperialist or neocolonialist. Recent developments in the professionalization and bureaucratization of the aid sector have increased the expert status of aid workers-their remuneration and lifestyles sometimes resembling those of corporate expatriates. Although this "normalization" has not brought them into the orbit of migration studies, more attention has focused recently on the social and cultural roles of aid workers, thus (implicitly) stressing their experience as migrants and workers. Mosse-an anthropologist with a previous career in development work - argues for a critical approach to the "world of [aid] professionals":

Strangely late and reluctantly, anthropologists have turned to the study of the social and cultural lives of global professionals themselves, their class position, biographies, commitments and anxieties. [. . .] international experts are, like their policy models, mobile and separated from contextual attachments yet, paradoxically, are a highly visible group in the capital cities of the developing world where, far from instantiating a cosmopolitan outlook that "encompass[es] the world's [cultural] variety and its subsequent mixtures', they occupy cultural enclaves of shared consumption, lifestyle and values." ${ }^{81}$

Likewise, Fechter and Hindman plea for a broader perspective on the day-to-day experiences of aid workers: "Understanding the world of aid workers is central to generating a literature on development that goes beyond accusation and blame, although viewing their lives also produces new avenues for reexamining the processes of development. Rather than seeing human resources programs or cultural training of aid workers as marginal to the project of aid, we claim that they must be considered as central to aid." ${ }^{82}$ While these authors may not conceptualize aid workers as migrants, they do refer to the global and mobile character of aid workers, and mention the role of human resources programs and cultural training in shaping the cross-cultural moves of these organizational migrants. This business surrounding the movement of aid workers and their families encompasses the entire migration period, starting before departure and ending with their lives

81 D. Mosse, "Introduction: The Anthropology of Expertise and Professionals in International Development," in Adventures in Aidland: The Anthropology of Professionals in International Development, ed. D. Mosse (Oxford: Berghahn, 20 I I), I 4 .

${ }^{82}$ Fechter and Hindman, Inside the Everyday Lives of Development Workers, 3. 
after return. Similar to soldiers and corporate expatriates, there are also psychological studies dealing with "culture shock" among aid workers abroad, and resocialization problems (mainly with regard to Third Culture Kids, or TCKs) upon return. ${ }^{83}$ In her work on American aid workers in Nepal, Hindman concludes that these private and domestic issues to some extent influence the development agenda and the power of the organizations involved: "Projects end not because their mission is achieved but because a family decides to allow their daughter to be educated in the United States." 84 As a result, the home is recreated abroad, "houses, schools, swimming pools, grocery stores were all built to sustain the life of the valuable scientists." 85

It is interesting that the careers of aid workers often display a generational path dependency, both forward (their children) and backward, as many have parents or family members who have been engaged as diplomats, colonial civil servants, or missionaries. The intergenerational reproduction of this type of work and migration is highlighted by David Lewis in his research among present-day British NGO workers, whose personal narratives reveal career histories shaped by experiences or family background. ${ }^{86}$ In a similar fashion Fechter stresses the parallels in the roles taken by women in both the colonial enterprise and global capitalism today, despite not doing paid work (as "trailing spouses"). 87

83 The home culture of the parents is referred to as the first culture, the culture of the host country as the second culture, and the culture of the expatriate community as the third culture. F. C. Byrnes, "Role Shock: An Occupational Hazard of American Technical Assistants Abroad," Annals of the American Academy of Political and Social Science 368, no. I ( I 966): 95-I08; D. Bardwell Mumford, "Culture Shock among Young British Volunteers Working Abroad: Predictors, Risk Factors, and Outcome," Transcultural Psychiatry 37, no. I (2000): 73-87; D. Pollock and R. E. Van Reken, Third Culture Kids: The Experience of Growing Up among Worlds (Boston: Nicholas Brealey Publishing, 2004); and J. Knörr, "When German Children Come 'Home': Experiences of (Re-)Migration to Germany-and Some Remarks about the 'TCK' Issue," in Childhood and Migration: From Experience to Agency, ed. J. Knörr (Bielefeld: Transcript-Verlag, 2005), 53.

${ }^{84}$ H. Hindman, "The Everyday Life of American Development in Nepal," Studies in Nepali History and Society 7, no. I (2002): I 26; quoted by I. Harper, "World Health and Nepal: Producing International, Healthy Citizenship and the Cosmopolitan," in Adventures in Aidland: The Anthropology of Professionals in International Development, ed. D. Mosse (Oxford: Berghahn, 20I I), I28.

85 Hindman, "The Everyday Life of American Development in Nepal," I 30 ; quoted by Harper, "World Health and Nepal," I 28.

86 David Lewis, as quoted in Mosse, "Introduction," I 5.

87 B. S. Yeoh and L.-M. Khoo, "Home, Work and Community: International Migration and Expatriate Women in Singapore," International Migration 36, no. 2 (I998): I59-I84; A.-M. Fechter, "Gender, Empire, Global Capitalism: Colonial and Corporate Expatriate Wives," Journal of Ethnic Migration Studies 36, no. 8 (2010): I 279-1 297. 


\section{Mainstreaming Migration History and Aid Workers}

In contrast to the gradual inclusion of soldiers, the above-mentioned specialist studies on (at times religiously motivated) aid workers are still left out from mainstream narratives and conceptualizations of migration and labor. To illustrate this we return to the four major reference works in the field of migration studies (Tables 4 and 5). The 20 I I encyclopedia edited by Klaus Bade et al. does not contain entries on missionaries or aid workers at all; this is explained, however, by the fact that it focuses on migration and minorities in Europe. In general, it becomes clear that when migration scholars focus on SouthNorth migrations, (religiously motivated) development aid is only discussed as part of the migration-development nexus, which means dealing with return migrants and remittances. Whenever attention is paid to North-South missionary activities and development aid, this is discussed in the context of (neo)colonialism. The movement of missionaries and aid workers as such is not considered as migration. In an entry on religious migration in the medieval era in the Encyclopedia of Global Human Migration, Tillmann Lohse suggests that because of the fluid boundaries between ascetics, pilgrims, and missionaries, they might perhaps better be characterized as travelers ${ }^{88}$ This categorization is especially characteristic of studies of Muslim migrations, where religiously motivated moves-often combining pilgrimage, teaching, and trade - cannot be traced back to a clear institutional center or state (or organization for that matter) and remain the topic of mobility and diaspora studies. ${ }^{89}$ In a similar fashion, aid workers are often excluded from studies of international labor migration, as they are often volunteers (or aid workers employed on local contracts).

Hoerder's monograph only contains references to missionaries from the eighteenth and nineteenth centuries in Asia and Africa. Although he mentions the cultural changes that were wrought by these religious practices, he pays little attention to missionaries as migrants. In line with the subaltern turn, he only briefly comments upon the negative attitudes of both Chinese authorities and the colonial powers in Latin America toward the opulent lifestyles of some foreign missionaries, as "[children] of the era of commercial capitalism." ${ }^{00}$ The role of mission-

88 See the entry of Lohse (pp. $565 \mathrm{ff}$. ), in Ness, Encyclopedia of Global Human Migration.

89 D. F. Eickelman and J. Piscatori, Muslim Travelers: Pilgrimage, Migration, and the Religious Imagination (London: Routledge, I990), 5-6, I2-I3, I75; Ho, The Graves of Tarim, 28-29.

90 Hoerder, Cultures in Contact, 190, 370. 
TABLE 4. Explicit attention to missionaries as migrants in four recent seminal publications in the field of migration history (I995-2013).

\begin{tabular}{lccrr}
\hline & $\begin{array}{c}\text { Number of entries } \\
\text { with explicit reference } \\
\text { to missionaries }\end{array}$ & $\begin{array}{c}\text { Number of pages } \\
\text { on which missionaries } \\
\text { are mentioned }\end{array}$ & $\begin{array}{c}\text { Total } \\
\text { number } \\
\text { of entries }\end{array}$ & $\begin{array}{c}\text { Total } \\
\text { number } \\
\text { of pages }\end{array}$ \\
\hline CSWM $^{a}$ & 0 & 0 & 0 & 0 \\
$\mathrm{CC}^{b}$ & $5[2.9 \%]$ & $0[0 \%]$ & 169 & 582 \\
$\mathrm{EMME}^{\mathrm{c}}$ & $0[0 \%]$ & 220 & $538^{\mathrm{d}}$ \\
$\mathrm{EGHM}^{\mathrm{e}}$ & $3[-]$ & $>600$ & $2763^{\mathrm{f}}$ \\
\hline
\end{tabular}

a Cohen, The Cambridge Survey of World Migration.

${ }^{\mathrm{b}}$ Hoerder, Cultures in Contact. Missionary activities are mainly discussed in the context of colonization.

' Bade et al., The Encyclopedia of Migration and Minorities in Europe. There are no entries on missionaries, probably as a result of the focus on migration to Europe from the seventeenth century to the present.

d We only counted the "Groups" entries (pp. 210-747).

e "Missionaries." Most entries deal with mission to migrants, instead of considering missionaries as migrants. See the entries in Ness, Encyclopedia of Global Human Migration by Lohse (pp. 565 ff.); Baggio (pp. $2222 \mathrm{ff}$.); and Battistella (pp. 268 gff.). Excluded here are entries on "pilgrimage" and "religious travel."

${ }^{f}$ Volumes 2-5; we have excluded volume I (prehistory).

TABLE 5. Explicit attention to aid workers as migrants in four recent seminal publications in the field of migration history (1995-2013).

\begin{tabular}{lccrr}
\hline & $\begin{array}{c}\text { Number of entries } \\
\text { with explicit reference } \\
\text { to aid workers }\end{array}$ & $\begin{array}{c}\text { Number of pages } \\
\text { on which aid workers } \\
\text { are mentioned }\end{array}$ & $\begin{array}{c}\text { Total } \\
\text { number } \\
\text { of entries }\end{array}$ & $\begin{array}{c}\text { Total } \\
\text { number } \\
\text { of pages }\end{array}$ \\
\hline $\mathrm{CSWM}^{\mathrm{a}}$ & 0 & 0 & 0 & 0 \\
$\mathrm{CC}^{\mathrm{b}}$ & $0[0 \%]$ & $0[0 \%]$ & 169 & 582 \\
$\mathrm{EMME}^{\mathrm{c}}$ & $0[0 \%]$ & $0[0 \%]$ & 220 & $538^{\mathrm{d}}$ \\
$\mathrm{EGHM}^{\mathrm{e}}$ & $5[-]$ & & $>600$ & $2763^{\mathrm{f}}$ \\
\hline
\end{tabular}

a Cohen, The Cambridge Survey of World Migration.

${ }^{\mathrm{b}}$ Hoerder, Cultures in Contact.

c Bade et al., The Encyclopedia of Migration and Minorities in Europe. There are no entries on aid workers, probably as a result of the focus on migration to Europe.

d We only counted the "Groups" entries (pp. 2 10-747).

e There is no index for "aid workers." Most entries deal with development aid delivered to migrants, instead of considering NGOs as institutions forging migration (of aid workers). Exceptions are the entries on professional migration. The emphasis is on contemporary history. See the entries by Colic-Peisker (pp. $783 \mathrm{fff}$.); Erima (pp. I 5 I $4 \mathrm{ff}$.); Odok (pp. $2326 \mathrm{ff}$.); Kuptsch (pp. $2757 \mathrm{ff}$ ); and Yeates (pp. 2343ff.) in Ness, Encyclopedia of Global Human Migration.

${ }^{f}$ Volumes 2-5; we have excluded volume I (prehistory). 
aries in nineteenth-century Africa in supporting colonial regimes by teaching indigenous people the value of working for capitalist enterprises (plantations, farms, mines) and the opening of training institutions $^{91}$ does not help scholars to develop a more detached view and analyze missionaries' activities in terms of labor or migration. The entries on missionaries in the Encyclopedia of Global Human Migration are mainly concerned with the mission among international migrants and refugees. The entries by Fabio Baggio and Grazziano Battistella mention how missionaries from Italy, Spain, Poland, Germany, and Ireland were requested to work among the migrants who in large numbers moved to the Americas. But again, no attention is paid to their own experiences as migrants. There is only mention of the continuation of charitable work by some congregations, such as the Scalabrini missionaries, in other parts of the world today, and the "flexibility" and "courage" needed for the job. ${ }^{92}$

With regard to aid workers, the more contemporary focus of the Encyclopedia of Global Human Migration results in some attention being paid to the rise of intergovernmental and nongovernmental organizations (NGOs). Again, however, the emphasis is on their role in shaping migration, and much less as an institution forging migration and employing migrants. In an entry on health care professionals as migrant workers, Nicola Yeates does mention the involvement of the United Nations and various national voluntary services in sending people abroad. Moreover, she mentions the role of religious migration, with nursing nuns and religious orders from richer countries moving to poorer ones to fill the gap left by the emigration of nurses ("brain drain"). ${ }^{93}$ Furthermore, in their entries on professional migrants and North-South migration, Colic-Peisker, Erima, and Edda Odok mention the role of foreign experts in executing projects funded through foreign aid and loans. ${ }^{94}$ This migration often leads to developing countries sending their citizens to developed countries in order to be trained. As Kuptsch remarks, there is a significant (moral) difference in terminology between highly skilled workers who relocate from low-income

\footnotetext{
91 Ibid., 4II.

92 See the entries of Baggio (pp. 2222ff.); Battistella (pp. 2689ff.) in Ness, The Encyclopedia of Global Human Migration.

93 See the entry of Yeates in Ness, Encyclopedia of Global Human Migration.

94 See the entries of Colic-Peisker: Erima (pp. I5I 4-I 5 I 8); and Odok (pp. 2326-2332) in Ness, The Encyclopedia of Global Human Migration. See also V. Colic-Peisker, "Free Floating in the Cosmopolis? Exploring the Identity-belonging of Transnational Knowledge Workers," Global Networks io, no. 4 (2010): 467-488.
} 
to high-income countries, labeled as brain drain (or brain gain), and highly skilled people moving from high-income to low-income countries being perceived as professionals in humanitarian aid. ${ }^{95}$

Overall, we conclude that missionaries and aid workers, like soldiers, are often left out from mainstream migration (and labor) studies because of their dominant position vis-à-vis the residing population that they join or the migrants whom they are assumed to help. Or, to use Manning's terminology, because they are "invaders." Moreover, the temporary nature of their move-albeit not in duration of stay, but in the intention to return after completing the project/mission — only further deepens the rift between them and the "real" migrants. Although migration is seen as part of their profession-within the confines and interests of the organization for which they work, no attention is paid to the migratory behavior of individual missionaries or aid workers. This is particularly unfortunate, because both aid workers and missionaries are not only deeply involved in cross-cultural contacts, but due to their power and status, even small numbers can cause fundamental changes in religion, language, norms, and values.

\section{Historiography and Qualitative Examples}

Whereas we should be very grateful to military historians for our knowledge of soldiers as migrants and workers, in the case of aid workers and missionaries we owe a debt of gratitude to the fields of church history, missiology, colonial history, area studies, and anthropology for providing us with a wealth of data. As mentioned above, the attention paid to aid workers as migrants is rather new and — surprisingly—results from a growing awareness of the historical link between colonialism and development. Academic journals such as Third World Quarterly and Critique of Anthropology have started publishing articles that explicitly make a comparison between nineteenth- and early twentieth-century missionaries and colonial civil servants. These authors deal with what Roderick Stirrat calls "a modern version of what people in the industry tend to see as the new 'white man's burden." 96 It is important, though, to mention here the complex realities of the history of mission. Whereas at times the humanitarian activities went hand in hand with conquest and colonization, they were also part of a civilizing mission and an

\footnotetext{
95 See the entry of Kuptsch in Ness, The Encyclopedia of Global Human Migration.

96 Stirrat, "Mercenaries, Missionaries and Misfits," 407.
} 
ethnographic interest in the cultural "other."97 As Peter Stamatov recently showed in the case of Catholic missionaries and later Quakers and Protestant reformists in Latin America, missionaries accused Spanish and Portuguese settlers of exploiting and abusing indigenous people in a "decidedly unchristian manner," and as a result, from the early modern period onward, even developed a pro-indigenist long-distance advocacy network that could be used in defense of the rights and interests of distant "others." The differences between Catholic and Protestant missions sometimes clearly reflected different political interests (and forms of imperialism) but also different ways of viewing potential converts. ${ }^{98}$ But as Pels and Salemink state, "even those missionaries who had little or no tolerance toward 'other' customs had to communicate the Gospel, and to learn another language to do so." 99 With regard to Muslim missions, Ho argues that — at least for the Hadrami diaspora in the Indian Ocean from the sixteenth century onward-there existed no such link with trade and conquest, and contacts were on the basis of exchange. The practice of building schools and mosques and learning the local language, however, is no different. ${ }^{100}$

The contradictions and tensions (religious) aid workers see themselves confronted with today have been addressed in biographies and autobiographies, such as Hancock's well-known Lords of Poverty ${ }^{101}$ on the international aid "business," and Morris's Despairing Developer ${ }^{102}$ on his experiences in the Middle East. These accounts-not always appreciated by (former) employers and coworkers-should of course be treated with caution. Similar sources include field reports from aid workers to inform donors or future personnel ("peer briefings") about their work practices. Examples of these are Willard Hanna's Bung Karno's Indonesia ${ }^{103}$ and Howard Beers's An American Experience ${ }^{104}$ on

97 P. Pels and O. Salemink, eds., Colonial Subjects: Essays on the Practical History of Anthropology (Ann Arbor: University of Michigan Press, I999), 29-3I; Stamatov, The Origins of Global Humanitarianism, 4-8, 13-18.

98 Stamatov, The Origins of Global Humanitarianism, 25, 45-72.

99 Pels and Salemink, Colonial Subjects, 30.

100 Ho, The Graves of Tarim, 28; S. Coleman and J. Elsner, Pilgrimage: Past and Present in the World Religions (Cambridge, Mass.: Harvard University Press, I995); Eickelman and Piscatori, Muslim Travelers, I990.

101 G. Hancock, The Lords of Poverty: The Power, Prestige, and Corruption of the International Aid Business (New York: Atlantic Monthly Press, I989).

${ }_{102}$ T. Morris, The Despairing Developer: Diary of an Aid Worker in the Middle East (London: I.B. Tauris, I99I).

103 W. A. Hanna, Bung Karno's Indonesia (New York: American Universities Field Staff, I96I).

${ }^{104}$ H. W. Beers, An American Experience in Indonesia: The University of Kentucky Affiliation with the Agricultural University at Bogor (Lexington: University Press of Kentucky, I97I). 
the work of American Universities Field Staff. These analyses tend to take a human resources management-and thus organizationalapproach to the process of migration, discussing as factors for failure or success of the project the different stages, such as "learning the local language" or "finding suitable housing." 105

This professional perspective on cross-cultural contacts, also reflected in the growing market of preparatory courses and in-country training programs, has culminated in the idea that aid workers themselves have no culture. ${ }^{106}$ In his book on development workers in Honduras, Jackson cunningly calls them "the Globalizers," illustrating how the difference in terminology between "international" and "national" staff, or "cosmopolitans" and "locals," actually reflects a difference in salary and status. ${ }^{107}$ This notion of "flexible experts" with "portable knowledge" is rooted in the postwar fight against Communism. As Mehos and Moon convincingly show in their contribution to a volume on empire and technopolitics in the global Cold War, this actually reflects a shift in policy. Through newly created organizations such as the United Nations, many of the experts who had developed careers within one state or colony could now find employment as globetrotting (technical) advisors. The authors use the example of the Dutch HVA (the "Handelsvereeniging Amsterdam") in the Dutch East Indies, which developed from a long-established colonial plantation enterprise to a management and consultancy firm in the field of agriculture. ${ }^{108}$ The already mentioned article by Stirrat also illustrates how NGOs with religious organizational roots, operating worldwide, have a similar sense of "duty, service and faith," and how the rhetoric of "good governance" and "institutional reform" within contemporary NGOs is not so different from that of colonial rulers and bureaucrats. ${ }^{109}$

Besides these institutional continuities, there is also a role for personal links. Both Lewis and Stirrat mention that many NGO personnel are the offspring of missionary forefathers, whereas those working for official agencies often are the children of colonial civil servants or

105 C. A. McFarlane, "Risks Associated with the Psychological Adjustment of Humanitarian Aid Workers," The Australian Journal of Disaster I (2004).

106 I. Brinkman, Bricks, Mortar and Capacity Building: A Socio-cultural History of SNV Netherlands Development Organisation (Leiden and Boston: Brill, 2010), 206.

107 J. T. Jackson, The Globalizers: Development Workers in Action (Baltimore: Johns Hopkins University Press, 2005), 93.

108 D. Mehos and S. Moon, "The Uses of Portability: Circulating Experts in the Technopolitics of Cold War and Decolonization," in Entangled Geographies: Empire and Technologies in the Global Cold War, ed. G. Hecht (Cambridge, Mass.: MIT Press, 20 I I ), 43, 66.

109 Stirrat, "Mercenaries, Missionaries and Misfits," 4I6 (about fieldwork in Sri Lanka in the I990s). 
overseas military personnel. ${ }^{110}$ Moreover, in her study of SNV Netherlands Development Organisation, Inge Brinkman notes the continuation of the colonial legacy in the contacts established by a new generation of volunteers with the white minority of settlers who stayed on in the former colonies: "The presence of Peace Corps volunteers, missionaries and white settlers was seen as reassuring for the young volunteers in faraway places. [. . .] as the possibilities for recreational activities were limited, any opportunity to go swimming, play tennis, go fishing or horse-riding was more than welcome. Such opportunities were more likely to occur in white circles than in African milieus." 111

Especially in the I96os, these young, "alternative" volunteers did have "a strong wish to integrate into local society and were wary of being associated with colonialism." 112 They learned the local language, ate the local food, wore the local dress, and had local partners. Although this identification with the victims of Western dominance is inherent in development aid, the recent academic debate also relates to changes taking place in the field itself. The processes of professionalization and bureaucratization have effected a change in the people involved in development and the locales in which it takes place. As Stirrat writes, "in the past it was a matter of doing things: making things such as roads, bridges, reservoirs and dams, planting forests or creating irrigation systems." ${ }^{113}$ Today, development is concerned with institutional reform and good governance and thus takes place in the capital cities: "Cocooned as they are in their expensive hotels and air conditioned vehicles, their contact with 'real people' is mediated through government officers, interpreters and go-betweens of various sorts." 114

In her work on aid workers in Cambodia, Fechter describes the tensions this produces for those who want to be "close to the people" and "work at grassroots level." 115 Like others, she distinguishes between aid workers (noting that most volunteers live in homestays or at the fringes of the city) and NGO workers (who live in middle-class Cambodian neighborhoods) on the one hand, and donor staff (who live in villas in the central city) on the other. Stirrat observes a similar divide between

110 Ibid., 4I6.

111 Brinkman, Bricks, Mortar and Capacity Building, 8I.

112 Ibid., I99-20I.

113 Stirrat, "Mercenaries, Missionaries, and Misfits," 4I I.

114 Ibid., 408.

115 A.-M. Fechter, "Capital Lifestyles? Aidworkers as Migrants in the City," lecture at the EAC symposium "The Expatriate Experience: Past and Present," The Hague, I I April 2013 . 
the development professional (careerist motivations, material benefits) and the NGO worker (self-sacrifice). Moreover, there is the group of "development tourists," who-according to Jackson-find "working abroad most appealing" to aid work and want "to learn about other people, learn a new language." 116 These differences within the category of aid workers seem to reflect a varying degree of organizational logic and control. As Lisa Malkki describes in her article "A Tale of Two Affects" on doctors and nurses working in zones of crisis for the Finnish Red Cross: "[they] were not stereotypical humanitarians with a calling to help humanity, let alone to sacrifice themselves for its sake. They were not soldiers, either-and certainly not missionaries. They were internationalist professionals both in practice and in occupational disposition." 117

In his study of volunteers with the Mennonite Central Committee (MCC) in Indonesia, Philip Fountain notes that the emphasis on "bonding" and "belonging" to the new culture is especially strong among expatriate missionaries. In his analysis of orientation courses provided by the MCC, he describes the "drinking tea with the locals" myth. This implies that volunteers should try not to have a sense of superiority as "expert expats," but rather come as guests_-and thus, again, another boundary is drawn. ${ }^{118}$

The increasing professionalization of the aid sector has led to the hiring of more senior experts, offering higher salaries (conform the international labor market), and enabling them to bring along their partner and children. As Brinkman describes with regard to Dutch aid workers, this change in policy from the I980s on resulted in fewer cross-cultural contacts, since "people with families were less likely to 'go native' and they built up their social networks according to their own preferences, at times within the ex-pat community." ${ }^{119}$ Fechter questions whether this increased use of the same services provided for corporate expatriates poses any moral objections. The character of the expatriate community is often described in terms of a "ghetto" or "enclave," and

116 Jackson, The Globalizers, 90; K. Simpson, "Doing Development: The Gap Year, Volunteer-Tourists and a Popular Practice of Development," Journal of International Development I6 (2004): 68I-692; Stirrat, "Mercenaries, Missionaries and Misfits," 4I3.

117 L. Malkki, "A Tale of Two Affects: Humanitarianism and Professionalism in Red Cross Aid Work,” in Radical Egalitarianism. Local Realities, Global Relations, ed. F. Aulino et al. (New York: Fordham University Press, 2013), 2 I 7-2 I 8.

118 P. Fountain, "Orienting Guesthood in the Mennonite Central Committee," in Inside the Everyday Lives of Development Workers: The Challenges and Futures of Aidland, ed. A.-M. Fechter and H. Hindman (Sterling: Kumarian, 20 I I), 89-93.

119 Brinkman, Bricks, Mortar, and Capacity Building, $20 \mathrm{I}$. 
comes with similar downsides, such as isolation and gossip, common in close-knit immigrant communities. Moreover, Rajak and Stirrat argue that aid workers' "failure at being cosmopolitan" and frustration about the loss of "youthful ideals of unmediated cross-cultural contact" actually result in nostalgia about home and empire. ${ }^{120}$ As Timothy Mitchell describes in his book Rule of the Experts, ${ }^{121}$ there exists a strong discrepancy between policy and practice, sometimes reinforcing global inequality rather than resolving it. This is also a major criticism voiced in studies on South-North migrations. As Rebecca Peters states in her article on Angolan and British health professionals, development has its own "mobility regime": "a global hierarchy that prevents some individual professionals, particularly those from developing nations, from realizing the same benefits of their cosmopolitan mobility as professionals from industrialized nations." 122

Although these scholarly debates on aid workers' lifestyles may serve a different research agenda than that of migration historians, they provide insight into the role of class, ethnicity, age, motive, family history, community size, and duration of stay. Notwithstanding their high status, the experiences of aid workers are to a large extent similar to that of immigrants. For one, there is the ever-present relationship between migration and social mobility. American aid workers in Honduras, for example, through their salaries and benefits, end up in elite social circles, having access to top business executives, government ministers, and directors of international development agencies. As one of Jackson's interviewees stated: "Somebody told me that the dumbest thing I could do is go back to the United States, where I would be just another speck of dust like everybody else." ${ }^{123}$ For many aid workers, the loss of social status upon return is actually a reason to move from country to country as posts become available, thus challenging

${ }^{120}$ D. Rajak and J. Stirrat, "Parochial Cosmopolitanism and the Power of Nostalgia," in Adventures in Aidland: The Anthropology of Professionals in International Development, ed. D. Mosse (Oxford: Berghahn, 20I I), I5. See also S. J. Matt, Homesickness: An American History (Oxford: Oxford University Press, 20 I I) on the relation between homesickness and return migration.

${ }^{121}$ T. Mitchell, Rule of the Experts. Egypt, Techno-Politics, Modernity (Berkeley: University of California Press, 2002).

122 R. Peters, "Development Mobilities: Identity and Authority in an Angolan Development Programme," Journal of Ethnic and Migration Studies 39, no. 2 (201 2), 277.

123 Jackson, The Globalizers, 94. This painful process of return and reintegration in the national workforce is vividly described in the memoir of three UN and Red Cross employees: K. Cain, H. Postlewait and A. Thomson, Emergency Sex (and Other Desperate Measures): True Stories from a War Zone (London: Random House, 2006). 
the temporary nature of this type of organizational migration. Finally, aid workers, like other immigrants, experience feelings of loneliness and alienation, which are central to most psychological studies. As one American economist mentioned in his interview with Jackson: "You don't fit back home because no one really understands what you do. And you can never fully fit in with the country you're working in because you'll always be a foreigner. [. . .] But when you go home and everyone is talking about their cars or their lawn mowers or whatever, you think, 'God, this place is even crazier than I remember. I need to go back to Honduras."' 124

As with soldiers, the nature of NGOs as organizations is most relevant to the experiences of aid workers abroad. The subsequent waves of "decolonization" (and for that matter secularization) and professionalization of development have changed the character of both aid workers and the locales in which they operate. There is now a broad spectrum of aid workers, divided on the bases of motivation, skill, and payment, ranging from volunteers to development professionals. Once employed, all aid workers have to follow the policy of their "headquarters" and tend to adhere to these "global agendas" in their private lives as well. ${ }^{125}$ One way of undermining the control of the organization is by moving from post to post. However, this dependency on development work for maintaining one's lifestyle can become "a new form of prison." ${ }^{126}$ Nevertheless, the case of aid workers shows that the definition of organizational migrants as those "whose migratory behaviour is primarily determined by the interests of the organization they have joined" works best for lower-status migrants and for mid-ranking businessmen. For higher-status officials and NGOs, there is more bargaining, more individual choice of destination, somewhat more control with regard to timing, length of stay, and so on. Their temporary, multiannual migrations can cross multiple geographic areas and even merge into the category of travel.

\section{Conclusion}

In this article we have tried to do two things: (I) explain why "organizational migrants" have been excluded from most mainstream (his-

\footnotetext{
124 Jackson, The Globalizers, 92.

125 Mosse, "Introduction," I 4.

126 Stirrat, "Mercenaries, Missionaries, and Misfits," 420.
} 
torical) studies on migration and labor, and (2) show that these mobile professionals have much more in common with other migrants and workers than is often assumed. In contrast to geographers, who are intrinsically interested in all kinds of spatial mobility, more recent academic specializations such as migration and labor history tend to be more exclusive.

As we have shown, the field of migration studies, especially its historical parcels, has largely resisted a broad and encompassing definition of human mobility. Most scholars implicitly or explicitly limit themselves to the more or less definite and "free" moves of the working class and forced migrations of refugees. The reason seems to be a curious mix of strange bedfellows. On the one hand, there is the dominance of (nation-)state definitions of what constitutes a migrant (people crossing international borders) and full members of that nation-state. On the other hand, the field is characterized by a highly ideological antistate current that aims to uncover the groups that have been marginalized and repressed by that very state. This combination of reproducing and fundamentally criticizing the gaze of the state has led to a de facto exclusion of people who are considered temporary movers and who are associated with the powerful, politically or economically-exemplified in this paper by soldiers and aid workers.

The availability of encompassing analytical tools and definitions, such as those offered by scholars like Wilbur Zelinsky, ${ }^{127}$ Charles Tilly, ${ }^{128}$ and Patrick Manning, ${ }^{129}$ has created some cracks in the armor of migration studies, however, without causing a real breakthrough. Studies such as Nancy Green's work on American artists and business elites in Paris, Saskia Sassen's and Adrian Favell's focus on elite and non-elite migrants in global cities, ${ }^{130}$ or Sanborn's focus on soldiers as migrants, for example, remain rather isolated from mainstream concerns and interests. This situation reflects a more general tendency in the field of social history (much more than economic history, in which business elites have received ample attention) ${ }^{131}$ to study the working classes and more broadly those segments of the population

127 Zelinsky, "The Hypothesis of the Mobility Transition."

128 Tilly, "Migration in Modern European History," I 976.

129 Manning, Migration in World History.

130 A. Favell, Eurostars and Eurocities: Free Movement and Mobility in an Integrating Europe (Malden, Mass.: Blackwell Publishing, 2008); N. L. Green, "Americans Abroad and the Uses of Citizenship: Paris, I9I4-1940," Journal of American Ethnic History 31, no. 3 (2012): 5-34; Green, The Other Americans in Paris.

131 As is witnessed by journals like the Business History Review and Enterprise and Society. 
that are deemed the victims of discrimination, exploitation, oppression, and exclusion. Organizational migrants are the perfect antithesis. These "repugnant others," at least in the eyes of many scholars, ${ }^{132}$ were primarily considered as the agents of imperialism, capitalism, and militarism, and in that sense the progressive i97os have left us a stubborn and self-limiting heritage. It seems no coincidence that in the subfields of both migration and labor history, Charles Tilly's analytical attempts to introduce broad definitions of migration ${ }^{133}$ and (with Chris Tilly) work ${ }^{134}$ have been only very partially accepted, if at all.

Our failure to free ourselves of these self-imposed conceptual limitations severely limits our understanding of why people move-or work - in the first place, as well as the effects their migration and working activities have on the people themselves, on those they join in the receiving society, and on the people they may return to. Our argument is not that class, power, or the type of migration do not matter-quite the contrary. Rather, for deeper insight into migration processes and labor relations, a broader perspective has many comparative benefits for world historians, and also for those who might remain interested in the classic topoi of migration studies. For that reason, a more systematic study of similarities and differences-with respect to the processes of working, moving, and settling-can enrich the fields of migration and labor history considerably. Organizational migrants are a particularly good example precisely because, due to their hegemonic position as (temporary) "invaders," they have the power to forge far-reaching cultural, political, cultural, and social changes (for better or worse), often much more than migrants who settle in large numbers but who basically have to follow the rules and norms of the receiving society, albeit at the same time changing these as well, as the scholarship on migration and acculturation has amply showed. ${ }^{135}$ These changes need not always support hegemonic and imperialist agendas and can have unintended effects, as shown in the examples of the humanitarian pro-indigenist activities of sixteenth-century Catholic orders in the

132 Much less so by receiving societies.

133 Tilly, "Migration in Modern European History," I976.

134 Tilly and Tilly, Work under Capitalism.

135 For a global historical overview of different membership regimes, see Bosma et al., Migration and Membership Regimes in Global and Historical Perspective. For a good summary of the scholarship on settlement processes of ordinary migrants, see Hoerder, Cultures in Contact, and Bade et al., The Encyclopedia of Migration and Minorities in Europe. 
New World, and the reform of race-based immigration policies in the United States upon the return of GIs and their Asian "war brides" after World War II. ${ }^{136}$

Due to its focus on class, labor history has made more progress to date by gradually including sailors and soldiers, although this integration is still somewhat piecemeal and sometimes occurs in a way that is too differentiated from how historians analyze other workers. As becomes clear in a recent formulation by Peter Way: "if the military is central to-and, in fact, productive of - those profound economic changes, it is necessary to conceptualise soldiers as war-workers, indeed as transnational labourers whose martial toil around the globe proved integral to the development of international capitalism." 137

Migration history has a long way to go, although geographers especially, as well as anthropologists, have largely paved the way. Their work is only waiting to be picked up by interdisciplinary migration scholars. In order to show how organizational migrants can be fitted in the fields of labor and migration history in a more systematic way, Figure I summarizes the full potential of the field along the axes of skills and institutional logic. The "skills" axis refers to the human capital of migrants and the skill premium they can derive from it. "Institutional logic," on the other hand, expresses the extent to which organizations can and do determine the migratory behavior of their employees. As the typology presented here is ahistorical, future research will have to make clear to what extent organizations and the people they turn into migrants show the same characteristics over time. In another context, similar questions have been posed both in migration and labor history, ${ }^{138}$ especially where it regards the extent of (un)freedom, coercion, and agency, and the insights could very well be used to further historicize the role of organizational migrants (Fig. 2). Whereas labor history by now has more or less covered the entire "Unterbau," with cautious

136 Stamatov, The Origins of Global Humanitarianism, 42-44, 70-7I; Wolgin and Bloemraad, “"Our Gratitude to Our Soldiers,"” 28.

137 P. Way, "Class-Warfare: Primitive Accumulation, Military Revolution, and the British War-Worker," in Beyond Marx: Theorising the Global Labour Relations of the Twentyfirst Century, ed. M. v. d. Linden and K. H. Roth (Leiden: Brill, 2014), 66. See also the comments of J. Lucassen ("Worthy and Unworthy Efforts: Europe as a Comparative Unit," Tijdschrift voor Sociale en Economische Geschiedenis I I, no. I [20I4]: I 20-I2I) on C. Lis and H. Soly's magnum opus, Efforts: Attitudes to Work and Workers in Pre-industrial Europe (Leiden and Boston: Brill, 2012), in which soldiers are conspicuously lacking.

138 A. Stanziani, ed., Labour, Coercion, and Economic Growth in Eurasia, I 7th-20th Centuries (Leiden: Brill, 2013); McKeown, Melancholy Order. 


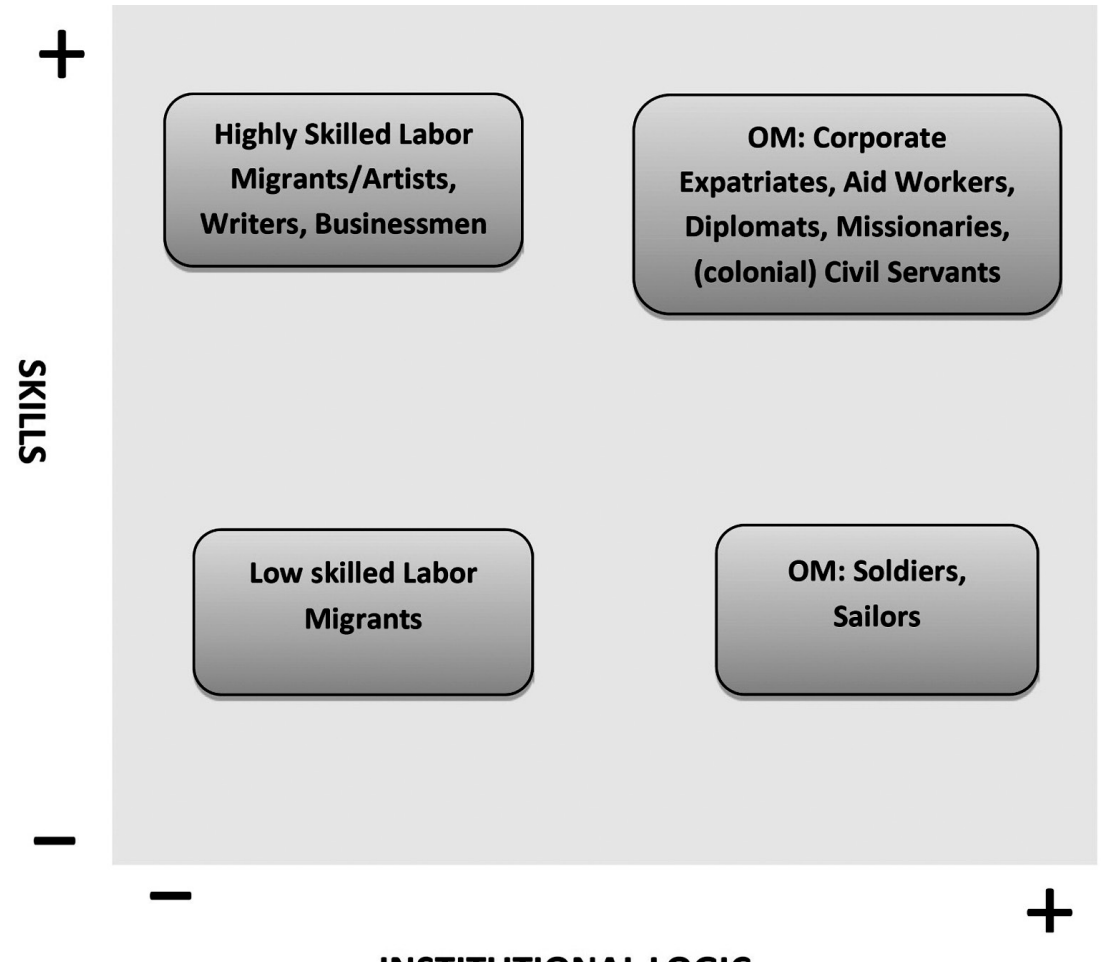

INSTITUTIONAL LOGIC

FIgURE 2. Putting organizational migrants $(\mathrm{OM})$ in a wider conceptual labor migration framework

expeditions up the skill ladder, most migration historians remain prisoner to their own state- and policy-imposed definitions and seldom venture outside the lower left box. With this paper we hope to have made clear that instead of risks and dangers, there are ample possibilities waiting out there. 
Page 40 is blank 